Doc. Ing. Oldřich Horák, CSc.

Vybrané problémy

STRAJEGG GKÉ

zpravodajské analýzy

\title{
Selected Problems of Intelligence Analysis
}

\section{Abstrakt:}

Schopnost poskytnout zásadní informace o události ještě předtím, než nastane, stavi zpravodajské analytiky do prvni řady boje s hrozbami terorismu, extremismu, širení zbrani hromadného ničení či aktivitami cizích zpravodajských služeb. Př́spěvek ukazuje aspekty zpravodajské analýzy, které maji velmi často vliv na kvalitu výsledné zpravodajské informace zpracovávané pro uživatele. Rozebírá problematiku zpravodajské analýzy ve spojení s uživatelem informací a současně se zabývá i úvahami v souvislosti s problematikou indikace príznaků a metodami varováni před překvapivými útoky protivníka. Cílem př́spěvku je zvýšit pozornost čtenářu a podnitit diskuzi k problematice predikci budoucích hrozeb v souvislosti s činností analytických týmů, protože jejich výsledky nejsou vždy dostatečně uživateli uznávány.

\section{Abstract:}

The ability to deliver information about an incident, long time before it has happened, puts intelligence analysts into the very first line of fight against the threat of terrorism, extremism, proliferation, or activities of alien services. The article deals with some aspects of intelligence research that often influence the value of final reports, presented to their consumers. It analyses intelligence database designated for its end users. It simultaneously reflects the question of indications and warnings against opponent's surprise attacks. Last but not least, the purpose of this article is both to attract the readers'attention to this theme and also to start debate on the methods of predictions of future threats, drawn up by analysts'teams, as their reports are not always suitably recognized by their end users.

\section{Klíčová slova:}

Výběr dat, zpracování informací, surová data, databáze, zpravodajská analýza, interpretace informací, třídění dat, zpravodajská agentura, uživatel, systém pohotovosti, nestátní aktér, terorismus.

\section{Keywords:}

Data selection, information processing, unprocessed data, database, intelligence analysis, information assessment, intelligence classification, intelligence agency, user, alert system, non-state actor, terrorism. 


\section{Úvod}

V důsledku často měnících se požadavků politických představitelů (uživatelů zpravodajské informace) se dostávají zpravodajské agentury do situace, ve které je preferována spíše krátkodobá (aktuální) zpravodajská informace. Potřeba dlouhodobé a systematické zpravodajské informace je potlačována a je víceméně v pozadí. I když politici necítí potřebu dlouhodobé informace, zpravodajští analytici tuto potřebu musí mít, protože pro svou analytickou činnost si musí vytvářet a aktualizovat databáze informací, poskytující výchozí podklady pro jejich práci.

Pro zpravodajskou agenturu je situace ještě složitější v tom, že politici využívají často otevřené zdroje, které mnozí z nich považují za rovnocennou náhradu zpravodajské informace. Mnohdy panuje představa, že v informační společnosti politik musí velmi dobře vše znát. Má ale zaneprázdněný politik čas na to, aby mohl číst domácí a zahraniční noviny a periodika a zpracovat své zdroje informací bez jakéhokoliv pomoci analytika? Vždyt' zpravodajský analytik potřebuje každý den až dvě hodiny k tomu, aby se jen seznámil s informacemi získanými v uplynulé noci.

Často se ale stává, že politik si na základě informace z otevřených zdrojů vyvodí vlastní závěry a od zpravodajského analytika chce potvrzení svých závěrů a rozhodnutí. Tím se stává, že současný analytik pracuje $\mathrm{v}$ prostředí, které je více konkurenční než kdy dříve a tato „soutěž o politika“ pravděpodobně zintenzivní ještě více $\mathrm{v}$ budoucnu.

Zpravodajská analýza je tradičním účinným nástrojem zpravodajské agentury, pracující ve prospěch posilování politického, vojenského, ale i obchodního a technického potenciálu státu. Metody zpravodajské analýzy využívaly už celá desetiletí i komerční subjekty, a ze zpráv úspěšných firem víme, že význam obchodního zpravodajství v poslední době ještě vzrostl. Jedná se o:

1. Techniky uplatňované ve zpravodajské analýze, jež jsou velmi podobné technikám používaným pro plánování a řešení problémů $\mathrm{v}$ různých organizacích.

2. Základní principy zpravodajské analýzy podobné těm, které se používají v jiných oborech lidské činnosti, a tyto podobnosti jsou obecně platné.

3. Metody mohou být převzaty z vědeckého výzkumu, strojírenství, práva a ekonomiky, a poté aplikovány ve zpravodajské analýze.

Určitým problémem zpravodajské analýzy je skutečnost, že informace shromážděné zpravodajskými technickými prostředky (snímky, signály, data a tak dále) nemohou být využity př́mo analytiky. Musí být nejprve převedeny ze surových dat do textových produktů nebo obrazů a teprve tyto potom mohou být využívány analytiky pro tvorbu zpravodajských informací. Zpracování a vytěžování jsou klíčovými kroky v převádění informací, shromážděných technickými prostředky, do zpravodajské informace.

Hlavní pozornost o zpravodajství bývá zaměřena na utajované shromažd’ování informací a speciální operace, které jsou pro veřejnost atraktivní a jsou tedy pomyslně tím podstatným, co zpravodajství dělá. Musíme si ale uvědomit, že samotné shromažd’ování ale produkuje pouze data a informace a nikoli výsledný produkt pro uživatele, tj. zpravodajské informace. Data a informace musí podstoupit vytěžení a zpracování analyticky předtím, než mohou být považovaný za zpravodajskou informaci a předány uživatelům. 
Zde je na místě otázka, co je tedy ve zpravodajství důležitější? Shromažd'ování informací jednotlivými zdroji, nebo analýza informací a produkce zpravodajských informací? Můžeme si odpovědět, že obojí je důležité, ale analýza informací je srdcem zpravodajské agentury. Přitom často bývá pravidlem, že omezené finanční prostředky pro zpravodajské agentury jsou více využívány pro zdrojové součásti, které často dostávají přednost před analýzou. A tak se často stává, že je shromažd’ováno mnohem více informací, než může být zpracováno nebo využito.

Sebelépe formulované požadavky na informace na zpravodajskou agenturu, shromažd'ování, vytěžení a zpracování informací mají potom jen malý význam, protože bez jejich zpracování analytiky nepřináší znalost. Pokud informace nejsou předány analytikům, kteří často spolupracují s experty v jejich př́islušných oblastech, nemohou být plnohodnotně využity. Analytici jsou schopni přeměnit informace do zpravodajské informace, která reaguje na potřeby politiků. Druhy vybraných analytických produktů, kvalita analýzy a produkce, čas zpracování aktuálních zpravodajských produktů, stejně jako produktů s vizí delšího dosahu, to jsou hlavní úkoly zpravodajství.

Proces analýzy informací je zpravidla zcela skryt před uživateli zpravodajských informací. A tak se stává, že prŕičinou řady největších zpravodajských neúspěchů bývá vedle špatné analýzy i fakt, že analýza nebyla provedena vůbec. A většina zbývajících nezdarů je prŕmým důsledkem selhání operativní akce, jež následovala po správné analýze. Informace, které jsou k dispozici, jsou zpravidla vágní a nikterak alarmující. Zpravidla je poznáme až při zpětném pohledu. Například před teroristickým útokem 11. záŕí 2001 existovaly jednotlivé informace o různých aktivitách (včetně výcviku pilotů), ty však vyvolávaly jen minimální zájem. V současnosti se objevila řada dokumentárních pořadů, které poukazují na chyby ve shromažd'ování a zpracování informací, ale ty vychází z hodnocení „,post mortem“, které může napomoci v př́ípravě nových analytiků.

Komise amerického Senátu pro vyšetřování 11. září, složená z řady odborníků, ve své zprávě vypočítává pochybení Federálního úřadu pro vyšetřování (FBI) a Ústřední zpravodajské služby (CIA). Nenašla ale důkaz, že by vládní agentury mohly útokům zabránit. Zpráva tvrdí, že agentury nedaly také dohromady informace, které mohly „významně posílit“ šance odhalit plán sítě al-Kai’dy na útoky unesenými dopravními letadly a předejít mu. Nikdo se nikdy nedozví, co se bývalo mohlo stát, kdyby se navzájem podařilo propojit více těchto různorodých informací.

\section{Informační základ}

Pro zpravodajskou analýzu informací a tvorbu zpravodajských produktů je důležité soustředit informace ze všech zdrojů, vlastních i cizích agentur. Spolupráce zpravodajských agentur je běžná uvnitř jednotlivých států. Lze si tedy položit otázku proč tedy nemít vytvořen informační základ? Prakticky by to znamenalo vytvoření společné databáze více agentur s jasně definovanými přístupovými právy. Stejně tak ale by muselo být definováno, jaké informace budou do této databáze vkládány, kdo je bude vkládat a s jakou mírou věrohodností obsahu těchto informací. Taková databáze by mohla být důležitým podpůrným prvkem tvorby dlouhodobé informace. Ona ale neexistuje, protože 
„,Soupeření“ zpravodajských služeb o př́zeň politiků či parlamentu, vede k otázce, kdo by měl být garantem společné databáze. Komu by to více prospělo, agenturám, nebo uživatelům informací? Nakolik by to přineslo zlepšení kvality informací a kdo by stanovil, $\mathrm{k}$ jakým informacím má kdo přístup?

Složitost vývoje situace v oblasti bezpečnosti, především různorodost hrozeb a potřeba zpracování jasné sady priorit požadavků pro shromažd'ování informací a jejich analýzu, přináší pro zpravodajské agentury potřeby rychlého zpracování získaných informací, ze kterých lze rychle odpovědět na zadané požadavky na informace. $Z$ uvedeného vyplývá, že problémem pro zpravodajskou agenturu není jen shromažd'ování informací, ale hlavně jejich zpracování a efektivní využití.

Složitou otázkou je problematika včasné informace a varování politiků před nebezpečím ohrožení státu. I když se v současnosti nejedná o nějaký útok proti ČR, přesto je nutno věnovat pozornost jak státním, tak nestátním aktérům, kteří jsou ochotni přistoupit na nebezpečí válečného konfliktu. Severní Korea a řada islamistických skupin jsou toho jasným př́kladem. Zde stojí zpravodajské agentury před složitou situaci, která je značně odlišná od té, která zde existovala za doby studené války.

\section{Minimalizace překvapení v bipolárním světě.}

Existence dvou proti sobě stojících koalic, obrovských vojenských organizací, vyžadovala řadu válečných příprav a nedovolovala zahájení konfliktu s překvapením v tom pravém slova smyslu. Nutnost doplnění vojsk mobilizovanými zálohami, př́ípravy techniky a další nutná opatření, včetně opatření v civilním sektoru, to představovalo jasné př́iznaky. Dlouhodobé sledování veřejných zakázek pro ozbrojené síly dává jasnou odpověd' na otázky modernizace a zvyšování bojových možností svazků. Sledování pohotovostních systémů jaderných sil, letectva, velení a dalších, neumožňovalo druhé straně získat výrazný předstih.

Sledování př́iznaků uvedené činnosti bylo alfou a omegou zpravodajských služeb. Poskytovalo varování před sovětským jaderným útokem, který mohl být překvapením ve strategickém měŕítku. Vypracované materiály pro analytiky dovolovaly sledovat standardní události života a výcviku vojsk.

Jakákoli zjištěná odlišnost byla podkladem pro analýzu s cílem zabránit překvapení. Tak mohly být odhaleny změny ve výcviku či postupné změny v systému bojové pohotovosti. Trvalé sledování a shromažd'ování informací vedly k hlubokému pochopení standardních operačních postupů druhé strany, tedy toho co vlastně představuje obvyklou činnost a jaké př́iznaky by mohly upozornit na př́ípadný útok.

Uvedené znalosti příznaků dovolovaly analytikům nejen upozornit politiky na určité nebezpečí, ale rovněž přesně zdůvodnit i příznaky, které je k těmto závěrům vedly. Sledování technickými prostředky, především s využitím satelitů, umožnilo specifikovat do detailu činnost vojenských sil druhé strany. Kontroly konvenčních zbraní, jednání o strategických zbraních, přinášely konkrétní poznatky k hodnocení příznaků nebezpečí hrozby. Takové závěry byly politiky dobře akceptovatelné, protože minimalizovaly nejistotu. 


\section{Teroristické hrozby}

Po 11. září 2001 se situace změnila. Nebezpečí číhající z útoků teroristických skupin má zcela jiný charakter, stejně jako „,běžná“ činnost potencionálních teroristů. Př́ípravy akce se mohou objevit na chatu při předávání zpráv, které ovšem mohou být součástí normální korespondence. Stejně tak se mohou signály o př́ipravách získat z telefonických hovorů nebo také může být signálem přerušení korespondence. To vše ale platí v případě, že známe toho, kdo za skupinou stojí nebo se projevuje jako její člen (přívrženec).

Teroristické hrozby, které jsou představovány nestátními subjekty, jsou tak nové a nepředvídatelné. Zjišs’ování možností, metod a cílů útoků je prakticky nemožné. Také je pravdou, že chování nestátních aktérů není omezeno standardními operačními postupy státních činitelů nebo předpisy, ze kterých vychází vojenské složky. Jinak řečeno, na rozdíl od studené války, kdy byly známy směry útoků a povaha nebezpečí, se zdá být zřejmé, že hrozby terorismu, které jsou představovány nestátními aktéry, jsou zcela jiného charakteru. $Z$ toho nepř́mo vyplývá, že zpravodajští analytici a političtí činitelé postrádají potřebnou představivost předvídat pravděpodobné hrozby terorismu.

Není to však zcela pravda, protože teroristé vyhlašují své, především ideologické cíle. Motivy a způsob jednání teroristických sítí jsou zpravidla dobře známé. Ve srovnání se signály, které generovaly vojenské organizace za studené války, jsou signály generované nestátními subjekty omezeny co do počtu a především jsou relativně slabé. V současnosti jsou nestátní síly ve srovnání se státními prvky omezeny v jejich operacích především dostupností zdrojů získávaných z pouhých tajných operací. Navíc výběr termínů jejich operací je omezen materiálními zdroji nebo osobami a v př́ípadě změn se zvyšuje pravděpodobnost odhalení zpravodajskými agenturami. Skutečnost, že teroristé musí útočit na silné a slabé stránky oponenta, aby bylo možné z výsledků generovat významný politický dopad, může být také použit jako vodítko k pochopení pravděpodobných hrozeb. Trvalé shromažd'ování a analýza informací, monitorování činnosti nestátních aktérů, teoreticky dává možnost pochopit a odhalit jemné signály změn, které vytvářjí varovné signály.

Indikace př́znaků a metody varování jsou založeny na klíčových pojmech a předpokladech, které musí být pochopeny a přijaty analytiky i veřejnými činiteli. Nemusí však být předpovědi konkrétních událostí. Mohou být pouze informacemi o hrozbách, které se zvyšují. Pokud politici trvají na přijímání takových informací, které mají poslat konkrétní podrobnosti o tom, co se chystá nebo přesvědčivé vysvětlení, proč se aktér chystá provést určitou operaci, pak se analytici dostávají do situace, kdy informace bude poskytnuta pravděpodobně príliš pozdě. Analytici a političtí činitelé musí překonat dilema, vycházející z preference politiků „vše nebo nic“ ve zpravodajské informaci.

\section{Indikace a metody varování}

Indikace a výstraha ve zpravodajských informacích je založena na detekci odlišnosti, které vyžadují trvalou analýzu modelů aktivit protivníka tak, že odráží „,normálnosti“ a mohou být identifikovány. V prŕípadě nedostatku jasného konceptu očekávaného chování protivníka a dobře definované seznamu varovných indikátorů mohou navíc poskytnout cenné služby, protože mohou posloužit jako způsob, jak nasměrovat shromažd'ování 
na jednotlivce, skupiny, zařízení či organizace, které se zdají být zapojeny do neobvyklé aktivity.

Analytici, kteří jsou seznámení blíže s objekty zpravodajského zájmu, jsou schopni najít bezvadné a přesvědčivé vysvětlení pro vznik některé z odlišností. Každá odlišnost vyžaduje další analýzu, protože nabízí způsob, jak odhalit klamání a podvod. Detekce odlišností činnosti u jednotlivců nebo skupin se nemusí objevit v prímé predikci operace protivníka. Vždyt' informace o skupině zahraničních studentů z Blízkého východu, kteří se učí létat, ale ne přistávat, naznačují, že analytici nebyli schopni rozpoznat, co vlastně taková informace pro varování znamená.

Jakmile jsou zjištěny indikátory odlišnosti od běžného stavu, politici musí rozhodnout o vhodné reakci, která je vhodná jako odpověd' na zvýšené hrozby terorismu. Je třeba si uvědomit, že změna situace v oblasti obrany a bezpečnosti může znemožnit plány protivníka. Mưže jej odradit od přijetí nežádoucí akce. Vzhledem k tomu, že protivník ztrácí přijatou reakci prvek překvapení, toto činí hrozby terorismu méně relevantní. Změna bezpečnostní situace může zpozdit činnost protivníka nebo jej také odradit od provedení operace. Prodleva do provedení př́ípadné modifikované operace protivníka dává možnosti získat čas, potřebný pro vyšetření zjištěných aktivit, stejně jako možnost narušit činnost protivníka, zadržení a identifikace jedinců, kteří jsou klíčem k blížící se operaci.

Protože i malá změna v oblasti obrany a bezpečnosti může odradit potenciální útok nebo zabránit operaci, může identifikace příznaků a zpravodajské varování překonat preference politiků pro „,všechno nebo nic“. Místo toho, aby politici přijímali nákladná opatření a extrémní reakce na potenciální hrozby terorismu, přijetí i relativně skromné změny v oblasti obranných a bezpečnostních opatření může zabránit protivníkovi v momentu překvapení, nebo zcela znemožnit plány protivníka, které jsou vytvořeny tak, aby splňovaly specifické strategické cíle.

Indikace a metody varování představují důležitý nástroj, který nabízí možnost rychlé reakce na současné teroristické hrozby. Nabízí zamyšlení nad možnostmi prostředků a technik shromažd’ování, což podporuje dlouhodobou analýzu při vytváření databáze znalostí přiznaků vznikajících hrozeb. Rovněž nabízí rozhodování jak lépe zaměřit úsilí shromažd’ování při analýze odlišností od známých modelů chování státních i nestátních aktérů. Pro analytiky ale také nabízí způsob jak překazit úsilí protivníka v klamání. Indikace a metody varování nabízí i způsob jak překonat dilema odezvy a obecnou nechut' politiků vynaložit značné náklady v reakci na hrozby terorismu. Současně nabízí strategické zajištění v oblasti zpravodajství, obrany a bezpečnosti státu.

Indikace a metody varování mohou nabídnout konstruktivní odpověd' i na současné bezpečnostní problémy. Je však zřejmé, že stanovení indikátorů po pádu studené války je mnohem složitější a může se zdát, že za současných podmínek některé z nich nereagují a mohou případně selhávat. Selhání je vždy třeba zvážit a využívat získané údaje v rámci shromažd'ování a analýzy pro další rozvoj zpravodajství. Indikace př́znaků a metod varování zůstávají významným a účinným nástrojem v úsilí zabránit překvapení, a odradit protivníka, který se snaží využít slabých stránek v bezpečnostní a obranné oblasti státu k dosažení svého cíle.

Interpretace zpracovaných informací je velmi důležitou složkou, protože prezentuje uživateli informace výsledky zpravodajské analýzy, a to nejen z oblasti př́znaků ohrožení národní bezpečnosti. Nástroje umožňující rychlý výběr záznamu s určitými 
daty (např. jména), analýzu vztahů mezi prvky navzájem, zobrazení kontextu a vzájemných vztahů jsou nejen neodmyslitelnou součásti analytického pracoviště. Grafické zobrazení výsledků analýzy vztahů je významným pomocníkem současného analytika a napomáhá i v přesvědčivosti prezentace.

\section{Závěr}

Zpravodajská analýza klade na analytika neobyčejně vysoké nároky. Zpravodajská agentura pracuje s informacemi. Smysl analýz spočívá v třídění a hledání vzorců mezi informacemi, popř. ve vytváření hypotéz, vysvětlujících jevy minulých nebo odhadující vývoj v budoucnosti. Analýzy obvykle představují řešení komplexního problému a jako takové se v současnosti nevyhnou využití nástrojů pro práci s databázemi, bez kterých si nelze zpravodajskou činnost představit.

Zpravodajské agentury jen velmi neochotně odhalují svá tajemství i běžné postupy, proto většina dostupné literatury, pojednávající o analýze, staví na teorii a praxi amerických zpravodajců, které nejsou vždy zcela aplikovatelné na evropské poměry zemí střední velikosti a z toho plynoucích omezených možností a ambicí zpravodajské práce. Přesto zůstává mnoho společného, nebot' práci bystrého analytického mozku nelze nahradit sebedokonalejší výpočetní technikou a i ty nejpřesnější snímky špionážních satelitů musí být interpretovány a zařazeny do kontextu za pomoci logiky, znalosti a zkušenosti analytiků a pokud možno i s použitím strukturovaných analytických metod. Zpravodajský analytik by měl samozřjejmě být na prvním místě odborníkem v problematice, kterou má ve své praxi analyzovat a až sekundárně by měl být vybaven i znalostmi o žádoucích analytických postupech. V tomto by mu měly přispět i nástroje pro práci s informační databází.

\section{Použitá literatura:}

CLARK, R. M. Intelligence Analysis: A Target-Centric Approach. 4. vyd., Washington, DC: CQ Press, 2013. 401 s. ISBN 978-1-4522-0612-7.

WIRTZ, J. J. Indications and Warning in an Age of Uncertainty. International Journal of Intelligence and Counterintelligence, 2013, č.3, str. 550-562. ISSN 1521-0561.

PARSELLE, Ch. Analytical/Intuitive Thinking. Dostupné z http://ezinearticles.com/? Analytical-/-IntuitiveThinking\&id=94800.

HORÁK, O. Zpravodajská analýza [Vojenská publikace]. 1. vyd. Praha: Ministerstvo obrany-Odbor vojskového průzkumu a elektronického boje, 2006, 173 s.

KOKUBO, A. Competitive Intelligence. IEEE Spectrum, srpen 1993, s. 44. ISSN 0018-9235. 